\title{
ASSESSMENT
}

\section{Teaching and Evaluating Skills for Undergraduate Research in the Teacher Education Program}

\author{
Tunde Szecsi, Charles Gunnels, Jackie Greene, Florida Gulf Coast University \\ Vickie Johnston, Elia Vazquez-Montilla, Florida Gulf Coast University
}

\begin{abstract}
Teacher candidates have lower participation in undergraduate research than students in other disciplines. To enable teacher candidates to develop skills for scholarly activities and to engage them in research activities, teacher education programs utilize diverse approaches. This article describes a strategy to promote undergraduate research among teacher candidates using a systematic course-based infusion of skills necessary for undergraduate scholarship. In addition, it reports on the undergraduate students' performance in research skills such as critical thinking, information literacy, and written communication in scholarly products over a three-year period. The results show an uneven but steady growth in research skills. Also discussed are the course and curricular modifications used by instructors to promote skill development for undergraduate research related to teaching.
\end{abstract}

Keywords: critical thinking, teacher education, teacher work sample, undergraduate research

doi: 10.18833/spur/3/1/5

To be effective, teachers must develop dynamic pedagogical strategies that are responsive to student's needs. This requires teachers to evaluate the effectiveness of different approaches so that ineffective techniques are reformulated or abandoned, whereas successful techniques are maintained and promoted. As a result, it is expected that teachers act as agents of change, becoming innovators in their profession, continually open to growth, inquiry, and research. One way to support inquiry and research skills is the infusion of scholarly experiences into undergraduate teacher education courses. Unfortunately, the research experience for undergraduate students in education is less prevalent than that offered in undergraduate study in other disciplines, such as math and biology, chemistry, and other natural sciences (Manak and Young 2014, 35).

Although undergraduate research in teacher education is less common than in other fields, a growing number of studies document faculty and student perceptions regarding undergraduate research for teacher candidates and its effectiveness in the United States and other countries (e.g., Dorner et al. 2017; Turner, Wuetherick, and Healey 2008; Yancovic-Allen 2018). Many of these studies focus on the benefits of future teachers' engagement in undergraduate research. These benefits include refined abilities for connecting educational theory and pedagogical practices to real-world implementation as well as the knowledge and skills for designing and interpreting research, inquiry, and collaboration (Madden et al. 2013, 16; White et al. 2016, 38). Despite the benefits of undergraduate research for teacher candidates, numerous obstacles may limit full implementation of undergraduate research in teacher education programs. These obstacles include lack of time and resources, the demands of education course content, and scarcity of faculty with the required research experience (Manak and Young 2014, 37; Munthe and Rogne 2015, 2; Myers et al. 2018, 143).

Though numerous obstacles are acknowledged, the benefits and learning gains seem to outweigh the challenges. Both faculty and teacher candidates (TCs) recognize the positive outcomes of scholarly activities; therefore, teacher educators pilot, implement, and document different approaches for infusing undergraduate scholarship into 
their programs (Myers et al. 2018). For example, Slobodzian and colleagues (2016) described a pragmatic model in which TCs engaged in self-analytic research through critical analysis of teaching practices that positively affect student learning. Similarly, action research as an avenue of combining teaching and research has the potential to foster future teaching (Yan 2017). In addition, Vaughan, Baxley, and Kervin (2017) found that the infusion of research assignments into a course was effective for research skill development.

Florida Gulf Coast University (FGCU) recently put a five-year plan into practice with the purpose of fostering and mentoring undergraduate scholarship for all students, including teacher candidates. The university faculty and administration initiated a university-wide educational reform as part of the institution's reaccreditation to improve transferable skills among students (i.e., written communication, information literacy, and critical thinking) through the integration of undergraduate research opportunities into the curriculum of every major. This reform, called FGCUScholars: Think $\sim$ Discover $\sim$ Write, required programmatic revisions to integrate skill-based lessons that introduced students to discipline-specific scholarly approaches. This design ensured that students would take at least three courses that engaged them explicitly in authentic course-based research experience, thereby promoting the development of these transferable skills. Under the FGCUScholars initiative, the teacher education faculty selected courses at the beginning, middle, and end of the teacher preparation program in which they could specifically target and evaluate the development of scholarly skills (critical thinking, information literacy, and written communication) that students could then use in research.

The purpose of this article is to describe the course-based infusion of skill development for undergraduate scholarship in teacher education and to share the undergraduate students' performance results related to critical thinking, information literacy, and written communication in scholarly products over a three-year period. In addition, the course and curricular modifications that instructors used to promote skill development for undergraduate scholarship related to teaching are examined. The article concludes by describing how this effort has engaged more students in undergraduate research experiences and provides additional recommendations based on these lived experiences and findings.

\section{Context}

The College of Education (COE) at FGCU offers six teaching certification programs, in which core courses are taken by all students in the majors of elementary education, early childhood education, special education, and secondary education (the last composed of three disciplinary-specific programs). To develop a scaffolded effort to master skills for undergraduate scholarship, the following courses were selected: (1) the beginning course (TSL 3080, Foundations of English as a Second Language, or ESOL), (2) the middle course, in the student's major, (RED 4350, Literacy Content and Processes), and (3) the capstone course (EDG 4937, Senior Seminar). In each course, a major assignment, called an artifact, was identified to assess TC skills (see Table 1).

\section{Beginning Course}

Upon entering the teacher education program, all TCs take Foundations of ESOL (TSL 3080), which examines issues of language and culture that are relevant for learners of English as a second language. The course creates an initial knowledge base in applied linguistics and cross-cultural communication for future teachers of culturally and linguistically diverse (CLD) students. The assignment Analysis of Family and Student Learning Environment provided opportunities for TCs to directly engage in research while exploring the sociocultural environment of CLD students via interviews and observations. This assignment required TCs to practice basic research skills, such as developing interview questions, analyzing and interpreting relevant sources, and then conducting and using critical thinking to analyze the interviews. Finally, TCs produced a research paper that concluded with recommendations for future teachers. In a scaffolded manner, the beginner TCs put into practice essential content specific knowledge, skills for conducting research, and dispositions to understand CLD students.

TABLE 1. Selected Courses and Artifacts

\begin{tabular}{|l|l|l|}
\hline Course identifier & \multicolumn{1}{|c|}{ Title of course } & \multicolumn{1}{|c|}{ Course artifact/assignment } \\
\hline Beginning course & TSL 3080, Foundations of ESOL & $\begin{array}{l}\text { Analysis of Family and Student } \\
\text { Learning Environment }\end{array}$ \\
\hline Middle course & $\begin{array}{l}\text { RED 4350, Literacy Content and } \\
\text { Processes }\end{array}$ & Strategy Application Project \\
\hline Capstone course & EDG 4937, Senior Seminar & Teacher Work Sample \\
\hline
\end{tabular}

Note $:$ ESOL = English for speakers of other languages 


\section{Middle Course}

In the course RED 4350, Literacy Content and Processes, the course scholarly assignment Strategy Application Project was piloted to explicitly develop the skills of critical thinking, information literacy, and written communication. The assignment required TCs to create a thematic unit plan using a total of 10 teaching ideas, which were all activities that employed a reading strategy to support a middle or high school student's comprehension of textual information utilizing relevant high-quality resources (i.e., books or articles). Consequently, the TC instructional decisions were made based on current research literature, taking into consideration the text structure in a content area (social studies, science, etc.). In this artifact, TCs were also required to use an evidence-based rationale for choosing each specific teaching idea, citing research that supported the reading strategy for improving comprehension.

\section{Capstone Course}

In this course, a Teacher Work Sample (TWS) was the capstone project for graduation and to meet accreditation and state approval requirements. This assignment also gave TCs the opportunity to demonstrate their ability to conduct research in teaching. The TWS is recognized as a tool for helping TCs to bring together theory and practice and to collect data to demonstrate their ability to positively impact preK-12 student learning (Benton et al. 2012, 370). The TWS represented the kind of planning, implementation, and assessment that should be ongoing in every classroom. It was a reflective narrative of a one- to four-week integrated unit of instruction in one subject area for one class rather than a typical research paper. The TWS included seven sections, beginning with an inventory of situational factors that impacted student learning in the student teacher's placement classroom and ending with a reflection on the entire teaching and learning process. With this artifact, TCs participated in action research as they developed an evidence-based documentation of teacher effectiveness.

These three courses and the selected artifacts served as milestones for the process and product of skill development for scholarship in teaching. The targeted skills were also embedded in almost every course in the teacher education program to ensure that TCs revisited and practiced these skills on a regular basis. From the beginning of the program, TCs were required to acquire and practice certain research skills and to become more and more independent research scholars as they progressed through the program. In addition to the implementation of this sequence of courses, annual evaluation of skill development and effectiveness for scholarship of TCs has been in place at the undergraduate level.

\section{Evaluation}

During the past three years, evaluation focused on the impact of the courses and assignments that were designed to enhance TCs' research skills in critical thinking, information literacy, and written communication. In addition, the instructors' pedagogical decisions regarding the course and assignment modifications were explored in an effort to improve teaching of these skills to students. The evaluation was guided by the following questions:

1. To what extent did the graduating teacher candidates' performance in combined skills change between the beginning, middle, and capstone courses over three years?

2. How did the teacher candidates' performance in critical thinking, information literacy, and written communication change in the beginning course between 2016 and 2018 ?

3. How did the teacher candidates' performance in critical thinking, information literacy, and written communication change in the middle course in the major between 2016 and 2018 ?

4. How did the teacher candidates' performance in critical thinking, information literacy, and written communication change in the capstone course between 2016 and 2018 ?

5. How did the instructors modify their pedagogical decisions and actions based on the evaluation of critical thinking, information literacy, and written communication skills to further foster teacher candidates' ability to complete high-quality undergraduate research?

\section{Evaluation Process}

As a complement to the instructor's regular evaluation of the course assignments, an additional evaluation process focusing on the research skills of critical thinking, information literacy, and written communication took place every May. In this annual evaluation, TCs who took the selected three courses between 2015-2016 and 2017-2018 served as the population for the evaluation. All TC artifacts in the selected three courses served as the pool from which a given number of artifacts were randomly chosen for evaluation (see Table 2).

Every May, a panel of education instructors completed the evaluation of artifacts in the beginning course (TSL 3080) and middle course (RED 4350), while a panel of instructors from other disciplines across the university conducted the evaluation of artifacts in the capstone course. The evaluation rubric had seven criteria, divided into three categories, as follows (see Table 3):

\section{Critical thinking}

1. Content development

2. Evaluation of information

Information literacy

1. Identification of and ability to access information and evidence

2. Effective use of information to accomplish a specific purpose 
TABLE 2. Number of Assessed Artifacts by Course

\begin{tabular}{|l|c|c|c|}
\hline Courses & 2015-2016 & 2016-2017 & 2017-2018 \\
\hline $\begin{array}{l}\text { Beginning: TSL 3080 } \\
\text { Foundations of ESOL }\end{array}$ & 23 & 12 & $\mathbf{2 3}$ \\
\hline $\begin{array}{l}\text { Middle: RED 4350 } \\
\text { Literacy Content } \\
\text { and Processes }\end{array}$ & 20 & 9 & 10 \\
\hline $\begin{array}{l}\text { Capstone: EDG 4937 } \\
\text { Senior Seminar }\end{array}$ & 28 & 18 & 15 \\
\hline
\end{tabular}

Note $: \mathrm{ESOL}=$ English for speakers of other languages

Written communication

1. Context and purpose

2. Genre and disciplinary conventions

3. Control of syntax and mechanics

This rubric was created using a modified version of the Critical Thinking VALUE Rubric of the Association of American Colleges and Universities (Rhodes 2010). In all cases, two instructors evaluated each artifact independently with this rubric; if the difference in rubric scores between the two evaluators was more than 4 points out of 28 , additional evaluators scored the assignment to achieve high inter-rater reliability.

The evaluation process included the following steps: (1) norming, (2) evaluating artifacts with the rubric, and (3) note-taking concerning additional areas of strengths and/ or areas for improvement. During norming, instructors developed a shared understanding of the rubric criteria and how to increase the inter-rater reliability. Then, with the rubric, they evaluated the artifacts with a numeric range of 1 to 4 and took notes about any significant issues regarding the three skills - critical thinking, information literacy, and written communication. These observational notes served as qualitative data that deepened faculty's understanding of the courses' strengths and areas for improvement.

\section{Data Analysis}

To determine how this curricular reform affected learning gains among TCs (questions 1-4), ANOVA permutation tests were used to compare assessment results of written artifacts produced by students in the beginning, middle, and capstone courses. All statistical analyses were run in $\mathrm{R}$ (R Core Team 2017). ANOVA permutation tests with a maximum of 5,000 iterations were run in the $1 \mathrm{mPerm}$ package of R (Wheeler and Torchiano 2016). Statistically significant patterns were described based on an alpha of 0.05 . The package ggplot 2 was used to create all figures (Wickman 2016). To answer question 5 regarding the instructors' pedagogical decisions and actions, the courses' syllabi, assignment descriptions, and instructors' reflections were analyzed qualitatively, following the data analysis spiral described by Creswell (2003).

\section{Results}

Graduating TCs showed significant improvements in the development of transferable skills associated with undergraduate scholarship across the three selected courses. Graduating seniors performed significantly better than lower-level students in the beginning and middle courses (see Figure 1). Graduating seniors showed a 21-percent improvement when scores were averaged across the seven assessed criteria of critical thinking, information literacy, and written communication. As would be expected by the overall increase, the number of TCs who succeeded in demonstrating the desired learning gains also changed across the three courses. The percentage of students who scored between a 3 and 4 on the rubric increased from 13 percent in the beginning course to 29 percent in the capstone, whereas the percentage of students that performed poorly, scoring between a 1 and 2, declined from 37 percent of students in the beginning course to only 7 percent in the capstone.

Overall, TCs showed better written communication skills than either critical thinking and information literacy skills (see Figure 2). However, students showed the greatest improvement in their critical thinking skills, improving by roughly 27 percent from the beginning to capstone courses. TCs showed similar improvements in their written communication and information literacy performance between the beginning and capstone courses, with 17.7 percent and 17.4 percent improvement respectively.

TCs showed variable learning gains among the associated courses during the three years of the program (see Figure 3). Graduating TCs made consistent learning gains in the capstone course during each year of the program, performing 5 percent better in year 3 than in year 1 of the intervention. In addition, students showed similar, although variable, learning gains in the beginning course, earning assessment scores that were 12 percent higher in the third year relative to the first year. However, TCs showed the highest learning gains during the second year of the program, before dipping during the third year. Although students performed better in the beginning and capstone 
TABLE 3. Evaluation Rubric for Assessing Teacher Candidates' Learning Gains

\begin{tabular}{|c|c|c|c|c|}
\hline Critical thinking & Capstone 4 & Milestone 3 & Milestone 2 & Benchmark 1 \\
\hline $\begin{array}{l}\text { Content } \\
\text { development }\end{array}$ & $\begin{array}{l}\text { Uses appropriate, relevant, } \\
\text { and compelling content to } \\
\text { illustrate mastery of the } \\
\text { subject, critical analysis, } \\
\text { and synthesis skills that } \\
\text { convey the writer's } \\
\text { understanding. }\end{array}$ & $\begin{array}{l}\text { Uses appropriate, relevant, } \\
\text { and compelling content to } \\
\text { explore ideas using critical } \\
\text { thinking skills within the } \\
\text { context of the discipline. }\end{array}$ & $\begin{array}{l}\text { Uses appropriate and rel- } \\
\text { evant content to develop } \\
\text { and explore ideas through } \\
\text { most of the work. }\end{array}$ & $\begin{array}{l}\text { Uses appropriate and rel- } \\
\text { evant content to develop } \\
\text { simple ideas in some parts } \\
\text { of the work. }\end{array}$ \\
\hline $\begin{array}{l}\text { Evaluation of } \\
\text { information; } \\
\text { conclusion }\end{array}$ & $\begin{array}{l}\text { Skillfully analyzes and } \\
\text { evaluates information and } \\
\text { evidence related to thesis; } \\
\text { conclusion is insightful, } \\
\text { logical, and justified based } \\
\text { on a skillful evaluation of } \\
\text { evidence. }\end{array}$ & $\begin{array}{l}\text { Adequately analyzes and } \\
\text { evaluates information and } \\
\text { evidence related to thesis; } \\
\text { conclusion is logical and } \\
\text { justified based on evalua- } \\
\text { tion of evidence. }\end{array}$ & $\begin{array}{l}\text { Attempts to analyze and } \\
\text { evaluate information and } \\
\text { evidence related to thesis } \\
\text { and use evidence in order } \\
\text { to justify conclusions. }\end{array}$ & $\begin{array}{l}\text { Takes information at face } \\
\text { value (little or no attempt } \\
\text { to evaluate quality of } \\
\text { information or evidence, } \\
\text { relationship to thesis, or } \\
\text { support of conclusions). }\end{array}$ \\
\hline Information Literacy & Capstone 4 & Milestone 3 & Milestone 2 & Benchmark 1 \\
\hline $\begin{array}{l}\text { Identification and } \\
\text { access of information } \\
\text { and evidence }\end{array}$ & $\begin{array}{l}\text { Demonstrates skillful iden- } \\
\text { tification and access of } \\
\text { high-quality, credible, rel- } \\
\text { evant sources to develop } \\
\text { ideas that are appropriate } \\
\text { for the discipline and } \\
\text { genre of the writing. }\end{array}$ & $\begin{array}{l}\text { Demonstrates consistent } \\
\text { identification and access of } \\
\text { credible, relevant sources } \\
\text { to support ideas that are } \\
\text { situated within the } \\
\text { discipline and genre of the } \\
\text { writing. }\end{array}$ & $\begin{array}{l}\text { Demonstrates an attempt } \\
\text { to identify and access } \\
\text { credible and/or relevant } \\
\text { sources to support ideas } \\
\text { that are appropriate for the } \\
\text { discipline and genre of the } \\
\text { writing. }\end{array}$ & $\begin{array}{l}\text { Has difficulty identifying } \\
\text { and accessing sources to } \\
\text { support ideas in the } \\
\text { writing. }\end{array}$ \\
\hline $\begin{array}{l}\text { Effective use of } \\
\text { information to } \\
\text { accomplish a specific } \\
\text { purpose }\end{array}$ & $\begin{array}{l}\text { Skillfully communicates, } \\
\text { organizes, and synthesizes } \\
\text { information from sources } \\
\text { to fully achieve a specific } \\
\text { purpose, with clarity and } \\
\text { depth. }\end{array}$ & $\begin{array}{l}\text { Communicates, organizes, } \\
\text { and synthesizes informa- } \\
\text { tion from sources. Intended } \\
\text { purpose is achieved. }\end{array}$ & $\begin{array}{l}\text { Communicates and orga- } \\
\text { nizes information from } \\
\text { sources. The information } \\
\text { is not yet synthesized, so } \\
\text { the intended purpose is not } \\
\text { fully achieved. }\end{array}$ & $\begin{array}{l}\text { Communicates informa- } \\
\text { tion from sources. The } \\
\text { information is fragmented } \\
\text { and/or used inappropriately } \\
\text { (misquoted, taken out of } \\
\text { context, or incorrectly } \\
\text { paraphrased, etc.), so the } \\
\text { intended purpose is not } \\
\text { achieved. }\end{array}$ \\
\hline $\begin{array}{l}\text { Written } \\
\text { Communication }\end{array}$ & Capstone 4 & Milestone 3 & Milestone 2 & Benchmark 1 \\
\hline $\begin{array}{l}\text { Context of and } \\
\text { purpose for writing } \\
\text { (Includes consider- } \\
\text { ations of audience, } \\
\text { purpose, and the } \\
\text { circumstances sur- } \\
\text { rounding the writing } \\
\text { task[s].) }\end{array}$ & $\begin{array}{l}\text { Demonstrates a thorough } \\
\text { understanding of context, } \\
\text { audience, and purpose } \\
\text { that is responsive to the } \\
\text { assigned task(s) and } \\
\text { focuses all elements of } \\
\text { the work. }\end{array}$ & $\begin{array}{l}\text { Demonstrates adequate } \\
\text { consideration of context, } \\
\text { audience, and purpose } \\
\text { and a clear focus on the } \\
\text { assigned task(s) (e.g., the } \\
\text { task aligns with audience, } \\
\text { purpose, and context). }\end{array}$ & $\begin{array}{l}\text { Demonstrates awareness } \\
\text { of context, audience, } \\
\text { purpose, and the assigned } \\
\text { task(s) (e.g., begins to } \\
\text { show awareness of } \\
\text { audience's perceptions } \\
\text { and assumptions). }\end{array}$ & $\begin{array}{l}\text { Demonstrates minimal } \\
\text { attention to context, } \\
\text { audience, purpose, and to } \\
\text { the assigned task(s) (e.g., } \\
\text { expectation of instructor } \\
\text { or self as audience). }\end{array}$ \\
\hline $\begin{array}{l}\text { Genre and disciplinary } \\
\text { conventions } \\
\text { (Formal and infor- } \\
\text { mal rules inherent in } \\
\text { the expectations for } \\
\text { writing in particular } \\
\text { forms and/or aca- } \\
\text { demic fields.) }\end{array}$ & $\begin{array}{l}\text { Demonstrates detailed } \\
\text { attention to and successful } \\
\text { execution of a wide range } \\
\text { of conventions particular } \\
\text { to a specific discipline and/ } \\
\text { or writing task(s) including } \\
\text { organization, content, pre- } \\
\text { sentation, formatting, and } \\
\text { stylistic choices. }\end{array}$ & $\begin{array}{l}\text { Demonstrates consistent } \\
\text { use of important con- } \\
\text { ventions particular to a } \\
\text { specific discipline and/ } \\
\text { or writing task(s), includ- } \\
\text { ing organization, content, } \\
\text { presentation, and stylistic } \\
\text { choices. }\end{array}$ & $\begin{array}{l}\text { Follows expectations } \\
\text { appropriate to a specific } \\
\text { discipline and/or writing } \\
\text { task(s), including basic } \\
\text { organization, content, and } \\
\text { presentation. }\end{array}$ & $\begin{array}{l}\text { Attempts to use a } \\
\text { consistent system for } \\
\text { basic organization and } \\
\text { presentation. }\end{array}$ \\
\hline $\begin{array}{l}\text { Control of syntax } \\
\text { and mechanics }\end{array}$ & $\begin{array}{l}\text { Uses eloquent language } \\
\text { that skillfully communi- } \\
\text { cates meaning to readers } \\
\text { with clarity and fluency, } \\
\text { and is virtually error free. }\end{array}$ & $\begin{array}{l}\text { Uses straightforward } \\
\text { language that generally } \\
\text { conveys meaning to read- } \\
\text { ers. The language in the } \\
\text { portfolio has few errors. }\end{array}$ & $\begin{array}{l}\text { Uses language that gener- } \\
\text { ally conveys meaning to } \\
\text { readers with clarity, } \\
\text { although writing may } \\
\text { include some errors. }\end{array}$ & $\begin{array}{l}\text { Uses language that } \\
\text { sometimes impedes } \\
\text { meaning because of errors } \\
\text { in usage. }\end{array}$ \\
\hline
\end{tabular}

Note: This rubric is a modified version of the Association of American Colleges and Universities (AAC\&U) Critical Thinking VALUE Rubric (Rhodes 2010). 
FIGURE 1. Assessment Data Collected on Teacher Candidates (2015-2018)

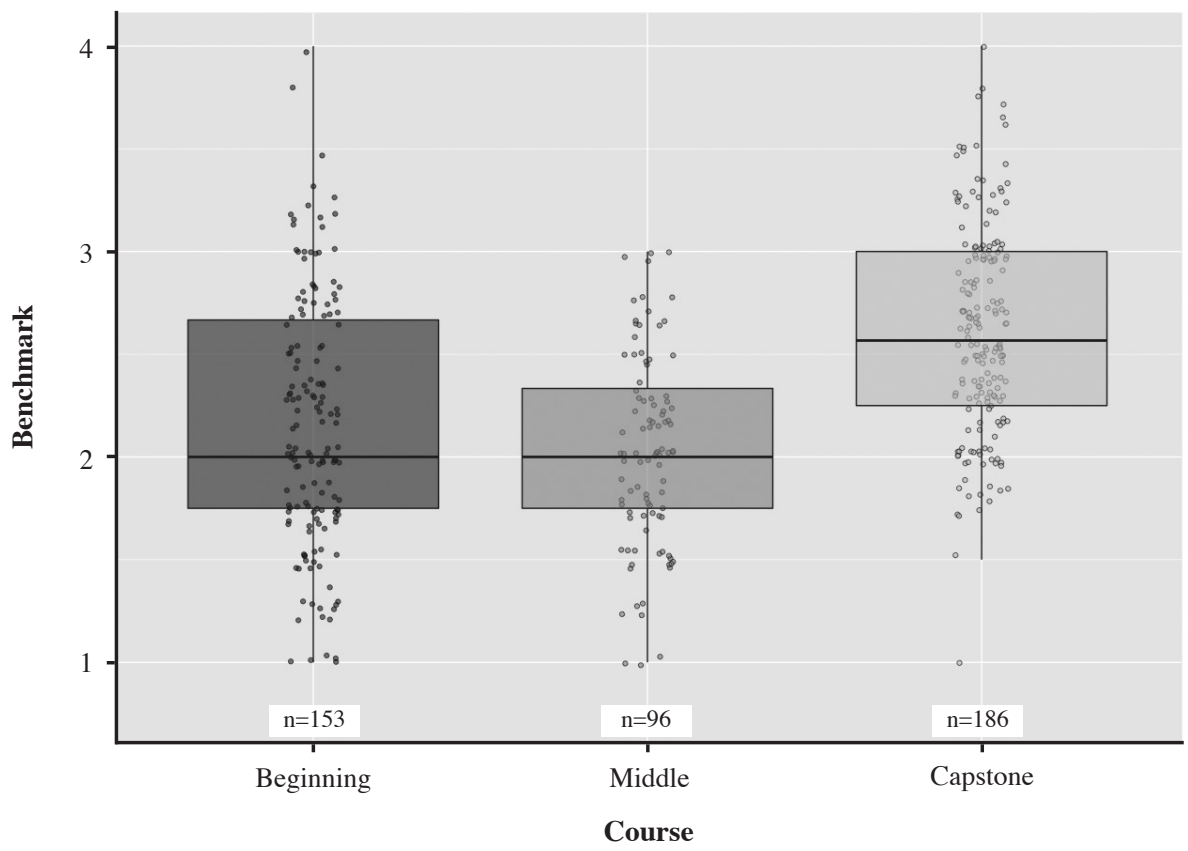

Note: The data represent the average score of seven criteria used to evaluate development of three transferable skills (critical thinking, information literacy, and written communication); individual student scores are represented by points. Students showed significant learning gains across the three scaffolded courses (ANOVA permutation test: $F=47.5 ; \mathrm{df}=2,432 ; p<0.001$ ).

FIGURE 2. Average Results of Assessment Data Collected from Teacher Candidates (2015-2018)

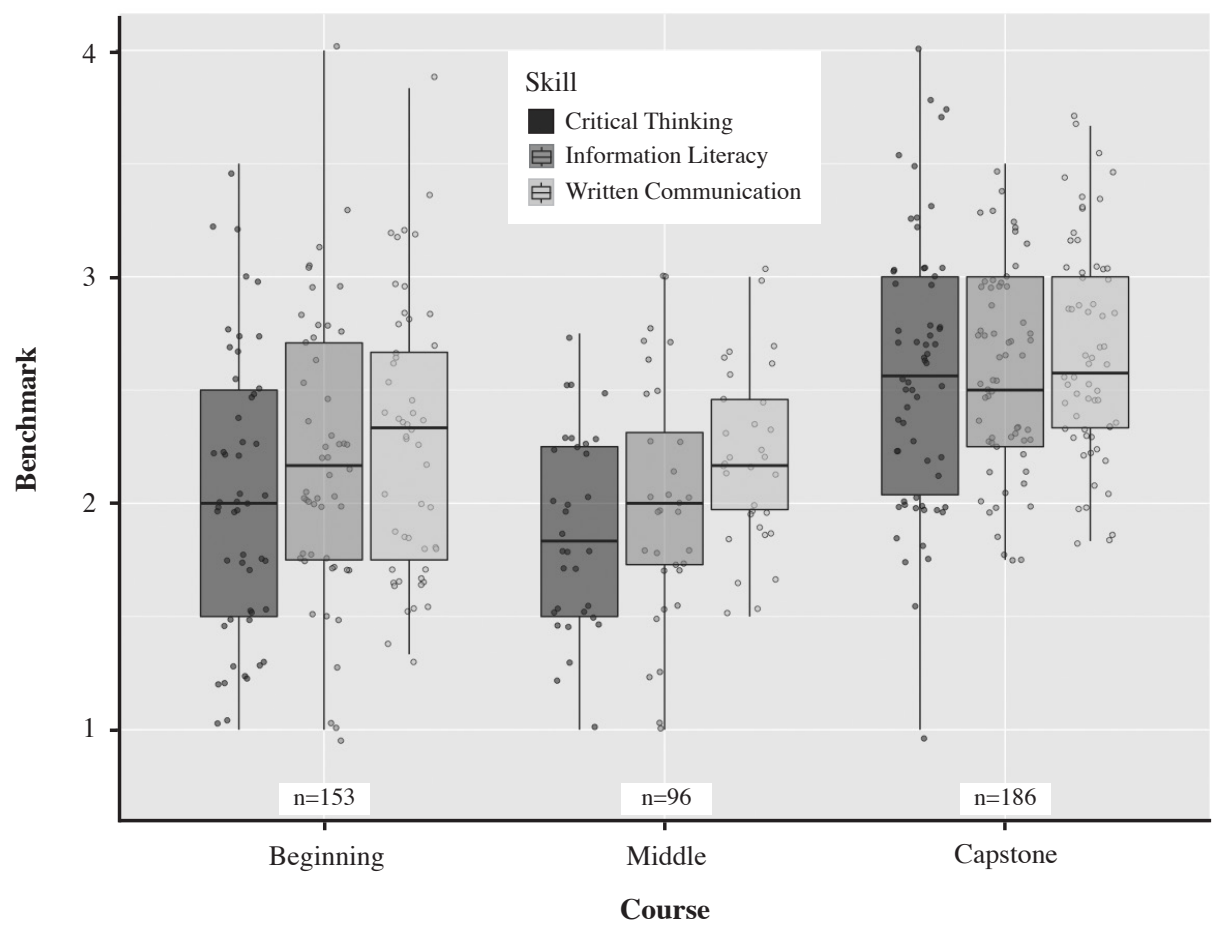

Note: Scores represent the average score for a student's critical thinking, information literacy, and written communication skills. Individual student scores are represented by points. Overall, education students showed significantly higher written communication skills than critical thinking and information literacy skills (ANOVA permutation test: $F=47.5$; $\mathrm{df}=2,432 ; p<0.001)$. However, students showed the greatest improvement in critical thinking skills, increasing by 27 percent between the beginning and capstone courses. 
FIGURE 3. Changes in Teacher Candidates' Learning Gains (2015-2018)

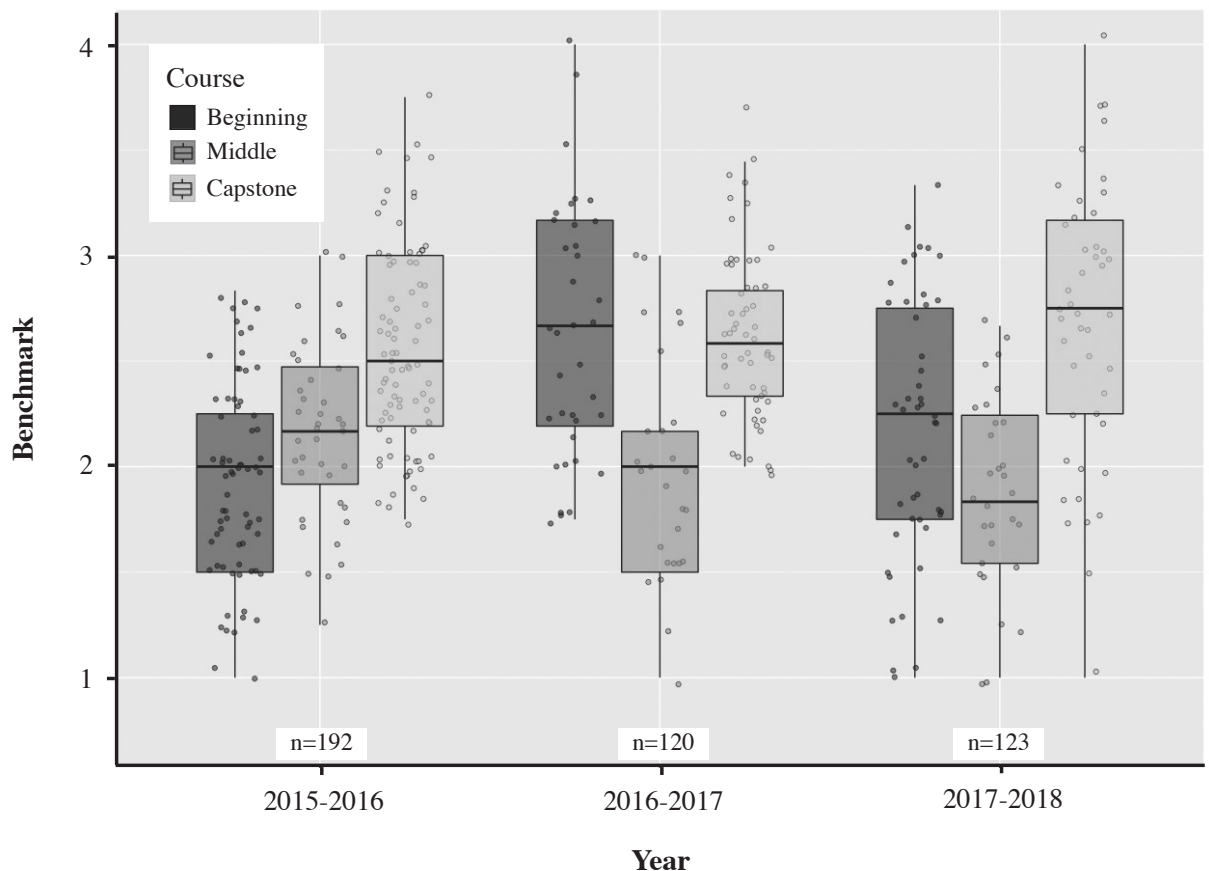

Note: These data represent the average scores of assessed artifacts for seven criteria for critical thinking, information literacy, and written communication. Individual student scores are represented by points. Teacher candidates showed variable learning gains among the associated courses during the three years of the program (interaction between course and year: $F=9.79$; $\mathrm{df}=4,426 ; p<0.001$ ).

courses, they showed consistent learning declines in the middle course; these students performed 13 percent worse in year 3 than in year 1 of the program.

\section{Modifications}

The yearly assessment results were shared and discussed with the instructors; based on the results they made pedagogical decisions to strengthen TCs in the targeted areas of critical thinking, information literacy, and written communication. The following modifications were implemented to address the areas needing improvement.

\section{Beginning Course}

In this course, additional instruction and guidance in proper research procedures, such as generating research questions, interviewing skills, and analyzing qualitative data, and increased scaffolding of academic writing were implemented. Relevant topics embedded in class content included a grammar review series, the use of exemplary articles from scholarly research papers using APA style, a workshop on how to navigate the library and locate articles in refereed journals, and information on developing research questions. As a result, the course expanded TCs' cross-cultural understanding and added more depth to the inquiry related to perceptions, beliefs, and framing of education from diverse perspectives, as generated by research questions.

\section{Middle Course}

The faculty teaching this course recommended modifying the pilot assignment, which resulted in the creation of a separate assignment in the form of a literature review. This change was determined to be a more effective approach to using literature and preparing TCs for the Teacher Work Sample in the capstone course. Furthermore, this new literature review was broken down into two parts: (1) the teaching idea or instructional routine, and (2) description and rationale of the research supporting the reading strategy utilized for the teaching idea, or explanation of how research had shown it to improve comprehension. By focusing on only two parts of this unit assignment, TCs developed their writing, critical thinking, and information literacy to foster discipline-specific comprehension. Additional instruction in specific writing competencies, citing research in APA style, and evaluating and synthesizing scholarly information was infused.

\section{Capstone Course}

The first-year evaluators of the Teacher Work Sample had a challenging time recognizing the presence of critical thinking within the large document of 60-100 pages produced in the capstone course. Although each TWS relied on a rich variety of resources, the artifacts did not reflect the information literacy typically found in a research paper. Therefore, the TWS was modified to enhance the TCs' ability to make 
effective use of the literature in this action research. TCs embarked upon a typical research-paper project investigating evaluation of teacher effectiveness in US schools. For candidates' future success as classroom practitioners, understanding teacher evaluation processes, its components, and the forces affecting evaluation processes was relevant and increased essential knowledge. To gain information about and understanding of the evaluation of teacher effectiveness, TCs read a series of articles by Darling-Hammond (2010, 2014), Goe (2013), and Minnici (2014). Seminar discussions on the measurement of teacher effectiveness and background information from the articles helped TCs identify their research topic and formulate research questions. Teacher candidates then embarked upon individual explorations of evaluating teacher effectiveness. A part of this exploration was a concise literature review to support their thesis and provide information to answer research questions and discuss their findings. Their explorations of effectiveness led to a deeper understanding of the importance of being proactive participants in their professional development and evaluation of their classroom practice.

Overall, modifications in the three courses targeted a gradual progression of skill development through which TCs became increasingly independent in the research process.

\section{Conclusions}

Research-based teacher education is an emerging trend in the United States and worldwide as part of strengthening teacher preparation in the twenty-first century (Afdal and Spernes 2018, 216). These research-based teacher education programs focus on learning experiences that foster skills such as critical thinking, analysis, and critical reflection skills (Cochran-Smith and Fries 2005). When teachers possess these transferable skills, they are able to continuously renew their pedagogical approaches and act as creators of knowledge rather than as solely recipients or transmitters of knowledge (Darling-Hammond 2017, 294).

The teacher education program in this study is currently completing the fourth year of the five-year educational reform, using the prior years' evaluation data for continuous improvement. In this study, the systematic yearly evaluation of teacher candidates' skill development has indicated that the course-based scholarly activities infused throughout the teacher preparation program impact TCs' skills and competency in conducting research. These findings substantiate the results of the study by Vaughan, Baxley, and Kervin (2017), in which they found positive outcomes that included increased research skills and emerging teaching dispositions because of the coursebased infusion of research skills. Through these experiences, teacher candidates gradually transform from consumers of research to producers of research that offers insights into critical issues emerging from their teaching practices (Yancovic-Allen 2018, 490).
By the completion of the capstone course, teacher candidates showed an increase in research skills, although there was some fluctuation in performance across the courses. The lack of clear linear increase in evaluated skills from the beginning to the middle courses can be explained by the different nature of the course artifacts: a research paper (first year) versus a literature review (second year). Such variation among courses across different years may also be partially explained by the use of a single assessment instrument that aligned with some assignments better than others. Evolving assignments, particularly in the beginning and middle courses, may explain some of the differences observed in years 2 and 3 of the program, during which students appeared to perform better in the beginning course than the middle course. Overall, these findings indicated that teacher candidates had better research skill performance when engaged in the complete research process, rather than only a literature review. However, there is improvement in skills demonstrated in the capstone project, likely the outcome of extensive practice in the development of the literature review required in the middle course. The positive change that was documented in the capstone project reinforces the need for a program-wide infusion of scholarly skills for undergraduate research, starting at the beginning of the program and continuing to and through the capstone course.

Eventually, these course-based scholarly activities allowed the TCs to share their research experiences beyond the classroom and disseminate their studies to a wider audience. These research events were the result of the five-year university-wide educational initiative that shed light on the importance of undergraduate research and generated more scholarly activities conducted by undergraduate students. For TCs, a recently established COE research symposium hosted numerous scholarly presentations delivered by undergraduate researchers. Other examples included but were not limited to a community-engaged research project with the Wonders Garden in Bonita Springs, a faculty-student publication on a family literacy program for immigrants, a joint publication on games as assessment tools, and research presentations at regional conferences. These outcomes of the infusion of research skill development in courses are notable when it has been uncommon for teacher candidates to share their research experiences within the university community and beyond (Manak and Young 2014, 37).

The infusion of research skills into courses and their systematic evaluation have the potential for positively impacting the overall teacher education program. The education faculty's participation in the evaluation at the undergraduate level allows them to reflect on the courses and assignments that target and document scholarly skill development. Furthermore, the faculty's pedagogical decisions regarding the courses, skills, and assignments are based on the yearly evaluation data, which generates 
intentional curricular modifications for further program improvement. Overall, these efforts serve as ongoing professional renewal for faculty (White et al. 2016, 47). Therefore, it is argued that the efforts to create and maintain research-based teacher education programs can generate benefits for both teacher candidates and teacher education faculty. These positive outcomes will ultimately serve students in preK-12 classrooms as new teachers enter the profession with a more scholarly mind-set.

\section{References}

Afdal, Hilde W., and Kari Spernes. 2018. "Designing and Redesigning Research-Based Teacher Education." Teaching and Teacher Education 74: 215-228. doi: 10.1016/j.tate.2018.05.011

Benton, Jean E., David Powell, Mary Ann DeLine, Alberta Sautter, Mary Harriet Talbut, William Bratberg, and Simin Cwick. 2012. "The Teacher Work Sample: A Professional Culminating Activity that Integrates General Studies Objectives." Journal of General Education 61: 369-387. doi: 10.1353/jge.2012.0032

Cochran-Smith, Marilyn, and Mary Kim Fries. 2005. "Researching Teacher Education in Changing Times: Policies and Paradigm." In Studying Teacher Education: The Report of the AERA Panel on Research and Teacher Education, ed. Marilyn CochranSmith and Kenneth M. Zeichner, 69-109. Washington, DC: American Educational Research Association.

Creswell, John W. 2003. Research Design: Qualitative, Quantitative, and Mixed Methods Approaches. Thousand Oaks, CA: Sage.

Darling-Hammond, Linda. 2010. Performance Counts: Assessment Systems that Support High-Quality Learning. Washington, DC: Council of Chief State School Officers.

Darling-Hammond, Linda. 2014. "One Piece of the Whole: Teacher Evaluation as Part of a Comprehensive System for Teaching and Learning." American Educator 38(1): 4-13. Accessed September 26, 2019. https://www.aft.org/sites/default/ files/periodicals/Darling-Hammond.pdf

Darling-Hammond, Linda. 2017. "Teacher Education around the World: What Can We Learn from International Practice?" European Journal of Teacher Education 40: 291-309. doi: 10.1080/02619768.2017.1315399

Dorner, Lisa M., Sujin Kim, Alice Floros, and Midheta Mujanovic. 2017. "Everybody Kind of Looked at Me Like I Was from Mars': Preparing Educators through Qualitative ServiceResearch Projects." International Journal of Qualitative Studies in Education 30: 669-687. doi: 10.1080/09518398.2017.1309587

Goe, Laura. 2013. "Can Teacher Evaluation Improve Teaching?" Principal Leadership 13(7): 24-29. Accessed September 26, 2019. http://www.lauragoe.com/lauragoe/Goe\%202013\%20-\%20 Can\%20Teacher\%20Evaluation\%20Improve\%20Teaching.pdf

Madden, Lauren, Louise Ammentorp, Jacqueline DeNarie, and Tara-Lyn Farrell. 2013. "Benefits of Faculty-Undergraduate Research Collaboration." CURQ on the Web 34(1): 15-19. Accessed September 26, 2019. https://www.cur.org/assets/1/23/ Fall2013_v34.1_madden.ammentorp.denarie.farrell.pdf

Manak, Jennifer, and Gregory Young. 2014. "Incorporating Undergraduate Research into Teacher Education: Preparing

28 Scholarship and Practice of Undergraduate Research
Thoughtful Teachers through Inquiry-Based Learning." CUR Quarterly 35(2): 35-38.

Minnici, Angela. 2014. "The Mind Shift in Teacher Evaluation: Where We Stand - and Where We Need to Go." American Educator 38(1): 22-26. Accessed September 26, 2019. https://files. eric.ed.gov/fulltext/EJ1023882.pdf

Munthe, Elaine, and Magne Rogne. 2015. "Research-Based Teacher Education." Teaching and Teacher Education 46: 17-24. doi: $10.1016 /$ j.tate.2014.10.006

Myers, Joy, Amanda G. Sawyer, Katie Dredger, Susan K. Barnes, and Reece Wilson. 2018. "Examining Perspectives of Faculty and Students Engaging in Undergraduate Research." Journal of the Scholarship of Teaching and Learning 18(1): 136-149.

R Core Team. 2017. R: A Language and Environment for Statistical Computing. Vienna, Austria: R Foundation for Statistical Computing.

Rhodes, Terrel. 2010. Assessing Outcomes and Improving Achievement: Tips and Tools for Using Rubrics. Washington, DC: Association of American Colleges and Universities.

Slobodzian, Jean, Nadya Pancsofar, Matthew Hall, and Anne Peel. 2016. "A Closer Look at the Pragmatic Model of Mentored Undergraduate Research in a School of Education." CUR Quarterly 37(1): 41-45.

Turner, Nancy, Brad Wuetherick, and Mick Healey. 2008. "International Perspectives on Student Awareness, Experiences and Perceptions of Research: Implications for Academic Developers in Implementing Research-Based Teaching and Learning." International Journal for Academic Development 13: 199-211.

Vaughan, Michelle, Traci P. Baxley, and Cole Kervin. 2017. "Connecting the Dots: A Scaffolded Model for Undergraduate Research." National Forum of Teacher Education Journal 27(3): 1-12. Accessed September 26, 2019. http://www.nationalforum.com/Electronic\%20Journa1\%20Volumes/Vaughan,\%20 Michelle\%20Connecting\%20the \%20Dots \%20NFTEJ\%20 V27\%20N3\%202017.pdf

Wheeler, Bob, and Marco Torchiano. 2016. "ImPerm: Permutation Tests for Linear Models, Version 2.1.0" Accessed November 18, 2018. http://CRAN.R-project.org/package $=1 \mathrm{mPerm}$

White, Sonia, Erika Hepple, Donna Tangen, Marlana Comelli, Amyzar Alwi, and Zaira Abu Hassan Shaari. 2016. "An Introduction to Education Research Methods: Exploring the Learning Journey of Pre-Service Teachers in the Transnational Programme." Asia-Pacific Journal of Teacher Education 44: 35-48. doi: 10.1080/1359866x.2015.1021294

Wickham, Hadley. 2016. ggplot2: Elegant Graphics for Data Analysis. 2nd ed. New York: Springer.

Yan, Chunmei. (2017). "You Never Know What Research Is Like Unless You've Done It!" Action Research to Promote Collaborative Student-Teacher Research." Educational Action Research 25: 704-719. doi: 10.1080/09650792.2016.1245155

Yancovic-Allen,Macarena.2018. "Pre-ServiceElementary Teachers' Perceptions of Conducting and Consuming Research in Their Future Professional Practice." Teachers and Teaching: Theory and Practice 24: 487-499. doi: 10.1080/13540602.2018.1438389 
Tunde Szecsi

Florida Gulf Coast University,

tszecsi@fgcu.edu

Tunde Szecsi is a professor and the coordinator for the elementary education programs at Florida Gulf Coast University (FGCU) in Fort Myers, FL. She earned her master's degrees in Hungarian, Russian, and English language and literature in Hungary. She obtained her PhD in early childhood education at the University at BuffaloSUNY. She has taught courses on elementary and early education and English for speakers of other languages (ESOL). Her research interests include multicultural education, culturally responsive teacher preparation, humane education, and heritage language maintenance.

Charles (billY) Gunnels is an associate professor of biology and director of FGCUScholars: Think Discover Write and the Office of Undergraduate Scholarship (for research, creative, and other scholarly work). His current research focuses on student learning, undergraduate research, animal behavior, and historical zoology. He teaches courses in biological statistics, behavioral biology, and environmental sustainability.
Jackie Greene is a faculty member of the College of Education at FGCU, where she coordinates the New Teacher Support Program. She also serves as assistant director of FGCU's Lucas Center for Faculty Development and as director of the National Writing Project. Her research interests focus on teacher preparation, professional development, and writing as inquiry.

Vickie Johnston is the program coordinator for FGCU's curriculum and instruction MEd program and teaches literacy and teacher education classes in the College of Education. Her research interests and published work include literacy, students with exceptionalities, diversity, and emerging technology integration in teacher education.

Elia Vázquez-Montilla, professor, is the former chair of FGCU College of Education Undergraduate Studies. She teaches graduate and undergraduate courses in ESOL as well as curriculum and instruction. She completed her BA and MEd in education at the University of Puerto Rico and received her PhD from the University of Florida, with majors in elementary education and multicultural bilingual education. Her research interests include teacher education, families, and the academic performance of English-language learners.

\section{Looking for a past SPUR or CUR Quarterly article? Visit CUR's online article search: https://bit.ly/SPUR-CURQSearch}

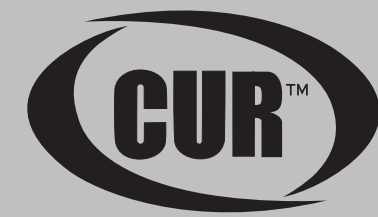

